\title{
The Effect of Gender, Age, Experience and Industry on Employees' Perceived stress: The Case of Bangladesh
}

\author{
Muhammad Rehan Masoom $^{1 *} \&$ Md. Kazimul Hoque ${ }^{1}$ \\ ${ }^{I}$ School of Business \& Economics, United International University, Dhaka, Bangladesh.
}

Received 02.02.2018; Received revised 04.06.2018; Accepted 23.06.2018

Available online 30.06 .2018

\begin{abstract}
Literature explaining the causes of widespread work-related stress often focuses more on the stressors, but give less sufficient attention to the perception of the employees who suffers. Stress is not an absolute state of the affairs, it is rather relative, and often depends on the 'definition of the situation' of the person of interest. Hence, measuring stress faces the issues of validity and reliability concerning the socio-economic context. The study adopts Cohen's Perceived Stress Scale (PSS10), the most popular stress measurement tool to explore the stress levels of the employees working in various industries in Bangladesh. The validity and reliability of the scale are tested with two distinguished yet related sample set; Sample one $(n=460)$ considers the employees of sixteen distinct industries, and sample two $(n=413)$ includes exclusively the employees of banking industry. Gender, Age, Industry, and 'year of experiences' are considered as the variables of interest to explore their relationships with perceived stress. The results suggest that the level of stress does not very significantly in accordance with gender; however perceived social stress differs in terms of Age, Experience and Industry that a person belongs.
\end{abstract}

Keywords: Perceived Stress, Industry, Cohen's Scale, Bangladesh.

Address of correspondence: Muhammad Rehan Masoom, School of Business \& Economics, United International University, UIU Bhaban, House\# 80, Road No. 8/A (Old 15) Satmosjid Road, Dhanmondi Dhaka 1209, Bangladesh.

E-mail: rehan_1611@yahoo.com

\section{Introduction}

Stress is the ubiquitous outcome of contemporary lives and a common result of modern-day economic activities. Stress arises when the resources seem inadequate to meet the ever emerging demands of the modern lives (Lazarus \& Folkman, 1987). Of course, stress is very personal and often associated with cataclysmic events of life; nonetheless, it's also the result of the perception of the person toward his or her own life experiences. Experiences vary from person to person as well as perception differs from one individual to another. Some factors, however, are more common than the rest to make anybody's life stressful. Researchers have identified some attributes that they regard as stressors. Obstacles accomplishing career goals, inequity in the form of scarce rewards relative to invested effort or provisions, excessive or poor environmental demand, the resentment of performance expectations and resource deprivation make life stressful (Wheaton, 1983). Stress also rises due to the difficulties related to participation in institutionalized roles (Pearlin,
1989), enduring interpersonal disputes (Avison \& Turner, 1988), status inconsistency, ambition-striving stress, and lifestyle incongruity (Dressler, 1988), disjunction of economic goals and educational systems (Farnworth \& Leiber, 1989). Socio-economic hardship such as poverty, corruption, violence, overpopulation, and turbulence (Eckenrode, 1984; Pearlin \& Lieberman, 1979), homelessness (La Gory, Ritchey, \& Mullis, 1990) and physical impairment (Turner \& Noh, 1988) are also some common stressors. There are numerous effects of living a stressful life.

Stress has both visceral and cognitive effects, hence biologically measurable indicators such as prolonged ill health for infectious, digestive, and respiratory diseases (Adler et al., 1994), psychological state such as hypertension and atherosclerosis (Sapolsky, 2004) and Social circumstances such as social disruption and social defeat (Stark et al., 2001) are the common measurement consideration. Sometimes the impact of one's experience on his or her subjective perception may also reveal the degree of stress that the person is enduring. 
The Perceived Stress Scale (PSS) estimates the extent to which circumstances in one's experience are assessed as stressful. The PSS was formed by Sheldon Cohen and his associates in 1983, (Cohen, Kamarck, \& Mermelstein, 1983 ) and emerged as one of the most used cognitive tools for estimating nonspecific perceived stress. It has been applied in the investigations determining the stressfulness of situations (Leon, Hyre, Ompad, DeSalvo, \& Muntner, 2007; McAlonan et al., 2007) and the effect of stressreducing interventions, (Cruess et al., 1999; Hölzel et al., 2009; Lane, Seskevich, \& Pieper, 2007; Marcus et al., 2003). It has also been applied to measure relations between subjective stress and psychiatric and physical disturbances (Culhane et al., 2001; Garg et al., 2001; Kramer, Ledolter, Manos, \& Bayless, 2000). The Scale is centered upon Lazarus's transactional model of stress that indicates the effect of a stressor depends on the interpretations of the individual who is experiencing it Though the real PSS comprises 14 items with a onedimensional construct of universal perceived stress (Cohen \& Williamson, 1988), nonetheless applying the 10-item model (known as PSS-10) as the measurement tool with a sufficient reliability estimates across worldwide is commonly witnessed (Taylor 2015). The principal forms consist of positively and negatively worded items (Cohen, S., Kamarck, T. and Mermelstein, 1983), and under exploratory factor analysis the negatively worded items have been identified to load onto a secondary factor departed from the positively worded items, contributing to the impression of a disposition effect (Cohen \& Williamson, 1988). The positively worded items are grouped in the term as 'Self Efficacy' and the negatively worded items are considered as the items of the factor, 'Perceived Helplessness' (Hewitt, Flett, \& Mosher, 1992).

Nevertheless, the first question of this quantitative venture is whether Cohen's PSS scale is a reliable measure is in the rising economy context? If it is reliable, whether it has the psychometric properties that would pass the threshold level of construct validity? Second, if the measurement procedure is both reliable and valid, whether there are differences in the level of stresses in accordance with gender, age, nature of work or industry and 'years of experience'. Third, how much the employees working in a particular industry (i.e. the banking sectors) are coping with the stresses in relation with the overall employees of various job sectors including the financial institutions other than banks. In this regard, the present study aims to explore the effect of Gender, Age, Experience and Industry on Perceived Stress.

\section{Literature review}

There is a growing concern on the reliability and validity of the PSS and analysis of the items shows a variation in different studies. Some provision for this approach has appeared. For instance, Hewitt, Flett, and Mosher (1992) observed that the perceived helplessness items administered to expect depression in both male and female while the positively worded items contributed to expect depression in merely female. The shapes of distinctive indicators of depression between genders suggest that the negatively worded items are drawing something nominal consideration rather than a means that can have a proper effect. Taylor (2015) indicates, treating the negatively and positively worded items as subscales to form two latent factors when fixing the covariance to zero bring a reasonably poorer fitting model than a correlated solution (Taylor, 2015). Again, the negatively worded items have been bringing about a secondary factor comprising method variance, where no significant correlation between the two latent factors has been found (Hyland, Boduszek, Dhingra, Shevlin, \& Egan, 2014). Though the prevalence of evidence is on the side of a multidimensional model, the point of departure has not been thoroughly settled particularly dealing with shortcomings in the methodological principle obtainable on differentiating between the nominal and process variation.

Across diverse circumstances, researchers report relatively good reliability values for scores of both the 14item and 10-item forms. For instance, Roberti, Harrington, Storch (2006) reported reliability values of .85 and .82 in an undergraduate sample for scores on the perceived helplessness and perceived self-efficacy scales, respectively (Roberti, Harrington, \& Storch, 2006). Very similar conclusions were reported in Taylor (2015) who studied of middle-aged adults (Taylor, 2015). One weakness for considerable reliability estimates set forth in the existing research is the unduly restrictive requirement of tau-equivalence for accurate reliability values (Graham, 2006) because it requires each item of a scale to have almost the similar amount of relationship with the unobserved characteristic (e.g., self-efficacy or perceived helplessness).

Previous studies suggest that the PSS predicts both objective physiological indicators of stress and elevated prospect for illness among individuals with greater anticipated stress levels. For instance, those with bigger scores (symptomatic of prolonged stress) on the PSS fend worse on physiological indicators of aging, (Epel et al., 2004) Cortisol levels (Malarkey, Pearl, Demers, KiecoltGlaser, \& Glaser, 1995; Pruessner, Hellhammer, \& Kirschbaum, 1999; Van Eck, Berkhof, Nicolson, \& Sulon, 2005), immune markers (Burns, Drayson, Ring, \& Carroll, 2002; Cohen, Doyle, \& Skoner, 1999; Glaser et al., 1999; Maes et al., 1999), depression (Carpenter et al., 2004), infectious disease (Cohen, Tyrrell, \& Smith, 1993; Dyck, Short, \& Vitaliano, 1999), wound healing (Ebrecht et al., 2004), and prostate-specific level of antigen in the male (Stone, Mezzacappa, Donatone, \& Gonder, 1999). Almira Osmanovic-Thunström and her associates indicates that health-related stress is very much prevalent in older adults, and outlined health-related factors such cognitive decline, multimorbidity and physical disability as the primary factors behind their perceived high stress (OsmanovicThunström, Mossello, Åkerstedt, Fratiglioni, \& Wang, 2015).

Conversely, the study of Bergdahl and Bergdahl (2002) implies, the prevalence of moderate stress was estimated to be the least in the 60-69-year and highest in the 40-44year age group. They also found that women of 30-34 years had a higher frequency of moderate stress than men in the same age group. They conclude, women in the 30 to 39-year age group are exposed to high stress and are thus a vulnerable group (Bergdahl \& Bergdahl, 2002). Similarly, the findings of Russo, Miller and Vitaliano (1985) indicate females had substantially higher scores than males on such perceived stressors as: isolation in the academic surrounding, faculty hostility, regulatory interferences, and expectations about facing the challenging role of the physician. Females also reported more syndromes of depression in response to stressors concerning the school atmosphere. These results underline anecdotal papers which have conferred the primary difficulties females have in a male-oriented medical surrounding (Russo, Miller, \& Vitaliano, 1985). Bernard Misigo (2015) investigated the 
influence of Gender on perceived stress level of undergraduate university students from three public universities in the western part of Kenya and found a significant difference between the stress mean scores of males and females (Misigo, 2015). His findings suggest female students reported higher stress levels than males.

There is a growing interest to recognize the roles and responsibilities that an employee need to perform in the bank and the level of stress she confronts due to her job. Caral Lopes and Dhara Kachalia (2013), surveying 80 employees working in various banks in Mumbai, India indicates that bankers faces a great deal of stress because of Role ambiguity and Role conflict, Responsibilities associated with the people around, work overload and time constraint, Lack of motivation, less scope for creativity as well as lack of support from the organization they belong (Lopes \& Kachalia, 2013). Similarly, based on random convenient sampling of 250 employees, Vinothini and Kishori (2016) indicates that due to long time working hours, role of conflict and political pressure employees of the banks felt high degree of occupational work stress (Kishori \& Vinothini, 2016). George and Zakkariya (2015) found that public sector banks have lower job-related stress when compared to private sector banks (George \& K.A., 2015). CN Ementa surveyed 113 bank secretaries' perceived stress (and coping) with a point rating scale of 30 -items that has reliability co-efficient of 0.73 , and found that administrative and clerical functions are the root causes of stress. She also indicates that there are no significant differences of perceived stress in relation with gender, work experience and marital status (Ementa, 2015). Bases on 537 employees (Public, 411; Private, 126), selected by disproportionate stratified random sampling, Samartha, Begum and Lokesh (2014) indicates that employees of the both private and public sector banks experience the same level of stress, nonetheless the causes may vary. From the regression analysis, they conclude that Job Conditions, Inadequate planning of work, Demands of family, Undue expectation from job, Lack of efficient manpower, Unforeseen contingencies and Performance pressure are the contributing factors for stress of people of Public Banks. One the other hand, employees of the private banks stressed up due to Physical Environment \& repressive union activities, Adaptability to change, Undue expectation from job and absence of employee involvement. On the basis of the results of the factor analysis, they outlined 13 factors as the major contributors of the stresses in banking sector (Samartha, Begum, \& Lokesh, 2014). While a number of studies outline the factors behind the high level of stress, none has addressed the issue of who are more stressed up than the rest.

\section{Method}

\section{Participants}

Selection of the respondents depends on the nature of the industry and the location of the office. A number of surveyors were sent to the numerous workplace located in Motijheel, Dilkusha, Gushan circle 1, Gushan Circle 2, and Dhanmondi that are known as the prime commercial hubs of Dhaka City. Data collection had been subject to the willingness and the permission of the offices. Since there was no list or sample-frame on which a randomization can be made, selection of respondents is broadly a nonprobabilistic approach in this case. However, neither the researchers nor the surveyors have any control on who would be the part of the sample or who would remain out of it, make it a less questionable than that of pure judgmental sampling. It is ensured that the size of the sample in the research is large enough for factor analysis and draws some scientific conclusions based on it.

Two distinct samples $(\mathrm{N}=460$ and $\mathrm{N}=413)$ were employed to analyze the level of perceived stress, one with employees from sixteen different industries (henceforth indicated as Sample One) and the other one with employees from the Banking Section (henceforth regarded as Sample Two).

Sample One consists of 347 male and 113 female, among which 222 belongs to 20 to 30 age category, 149 respondents are between 30 to 40 , other 52 persons are in 40-50 age-bracket and 37 individuals are above 50 but below the official retirement age of 60 .

Sample Two consists of 333 male and 80 female, among them 140 belongs to 20 to 30 age category, 204 respondents are between 30 to 40 , other 37 persons are in 40-50 age-bracket and 32 individuals are above 50 but below the official retirement age.

\section{Instruments and Procedure}

The research intends to explore the level of perceived stresses of the people who are in various kinds of employment by using the 10-item forms of PSS of Sheldon Cohen and his associates. Responses of the items include (0) never, (1) almost never, (2) sometimes, (3) fairly often, and (4) very often (For items, please consider table 1). In addition, some basic demographic data such as gender and age, along with relevant information like year of experience were collected with the self-reportable questionnaire. At the time of the surveys, a cover letter informing the purpose of the study and the confidentiality of the respondent's identity were assured in a formal letter.

\section{Data analysis}

The structural validity of the scale was verified using Confirmatory Factor Analysis (CFA) and the reliability of the items was being tested with Cronbach's alpha. To determine the Perceived Stress of the respondents, the positively stated items (4 statements) are recoded and assigned the value in a way that the more the positive, the less the score. Hence, the higher cumulative score may indicate the higher stress, and the cumulative score on the scale can range from 0 to 40 . To describe the scenario in relative terms, any value ranging from $0-13$ proposed to be considered low stress, values from 14-26 may indicate moderate stress and cumulative scores equal or above 27 implies high perceived stress (Cohen et al., 1983). It is expected that most of the score may fall in the moderate stress level and some values may fall in the low or high level.

For analytical purpose, the research intends to compare (a) whether there are any differences regarding the stress level in accordance to the gender; (b) do distinct agegroups have different level of stresses; (c) does type of industry have any effect on employees' stress level; (d) whether or not stress-level goes up or down with that of the years of experiences. To measure the differences of the level of perceived stress is caused by Gender, $t$ test is applied. The test not only helps to compare but also may provide the idea that whether it can be hypnotized that there is a relationship between the gender and the level of stress. The one-way analysis of variance (ANOVA) is applied to determine whether there are any statistically significant differences between the means of the variables 
of interests. Here, the Cumulative score of Self-efficacy (4 items), Perceived helplessness (6 items) and Perceived social stress (all 10 items) are treated as dependent variable and 'Age Group', 'Year of Experience', and 'Industry' are considered as independent variable. The age groups are categorized as from 20 to 30 , from 30 to 40 , from 40 to 50 and from 50 to 60 as four distinct categories. The experiences are categorized as from 0 to 2, from 2 to 5 , from 5 to 10 and above 10 as four distinct categories.

\section{Results}

\section{Scale statistics}

The reliability coefficients (Cronbach's alpha value, if the scale is considered as unidimensional) for sample one (Sixteen industries) based on Standardized Items is 0.69, and for sample two (Banking Industry) is 0.66 . Though, the commonly recommended alpha value is 0.70 (Nunnally \& Bernstein, 1994) to reach the acceptance level, and for the study for both the sample may slightly fall short, nonetheless reliability may not be an issue since previous studies already proved that the scale is replicable in various context in numerous nations. Further, in various occasions it has been seen that reliability value exceeding the margin of 0.50 is taken for further analysis (Nunnally \& Bernstein, 1994). Hence, the reliability of the scale may not be beyond questionable, nonetheless further analysis can be considered with the level it has achieved with the data. Therefore, the study indicates, Cohen's PSS scale is a reliable measure is in the rising economy context; nonetheless any future research considering adopting the scale may need to be cautious about the reliability.

For construct validity, Discrepancy is set as "Maximum Likelihood", and the result of hypothesis testing in model indicates the appropriateness of the assumptions. The standardized factor loadings were presented in table 1 . Overall, standardized factor loadings exceeded 0.4 , except the item 8 (how often have you felt that you were on top of things). However, since the sample size is higher than 300 , single factor above 0.3 may not harm the construct itself (Hair, Black, Babin, Anderson, \& Tatham, 1998). Examination of the fit indexes in Table 1 reveals that the 2factor models fitted well. Therefore, the study proves that it has the psychometric properties that pass the threshold level of construct validity.

\section{Overall descriptive stress levels}

Findings imply that 24.8 percent of the employees working Sixteen distinct industries fall in low category, 71.5 percent in the moderate category and 3.7 percent in the high category (consider table 2 (a)). In comparison, 22.5 percent of the employees working in Banking Industry fall in Low category, whereas 72.4 percent in the Moderate and other 5.1 percent in the High category. Please consider table 2(b) for detail. These values can be considered as the general baseline with which the values of other demographic and economic variables can be compared to reach at a conclusion. Data suggests that about one-third $(30.1 \%)$ of the female respondents categorized in 'low' in Perceived Social Stress Scale in comparison to near about one-fourth $(23.1 \%)$ of the male. Again, female $(7.1 \%)$ comprises more than twice than that of male $(2.6 \%)$ in High category of Perceived Stress.

Similarly, female $(7.5 \%)$ working in the banks reported to feel slightly higher level of 'High' PSS than that of male $(4.5 \%)$. If the high level of Perceived Social Stress is compared with different age categories, the findings suggest that respondents above 50 years of age $(10.8 \%)$ are more stressed than rest of the age groups. In addition, a considerable number of respondents $(5.8 \%)$ between the ages of 40 to 50 years perceived high stress. People above 30 but below 40, are the least suffered of high stressed $(0.07 \%)$. However, we need to be cautious to make a general judgment about the age and stress relation, since these variables are not statistically tested as far. People working in the industries like Agriculture and Information \& Publishing, tend to fall in bipolar end; less number of respondents fall in the moderate category (50 percent and 47.6 percent respectively). People working in the industries such as Non-governmental Social Service (14.3\%), Manufacturing of Basic Metals (13.3\%), Agriculture (10.0\%), and Information \& Publishing (9.5\%) have the highest level of High Stress Level. Conversely, employees of industries like Pharmaceuticals (48.0\%), Information \& Publishing (42.9\%), and Agriculture (40.0\%) comprise the highest level of Low Perceived Social Stress Level. None of the employees of Architecture, Public Sector, Education, Financial \& Insurance, Pharmaceuticals, and Commercial Energy Sector perceived high level of stress. A considerable number of employees $(6.5 \%)$ who have above 10 years of experiences are facing high social stress. Please consider Table 2 for detail.

Comparatively, people of age between 30 to 40 years (6.9\%) working in bank feel high stress than the rest. No bankers above 50 years of age have high level of stresses. Regarding the years of experience, employees of the banking industry that are working more than 2 but less than 5 years in the bank are least in numbers $(2.8 \%)$. For detail please see Table 3 .

The level of stresses that the males face does not significantly differ in accordance with the industry they are employed, however, the study indicates that females working in the banks $(\bar{x}=18.73)$ suffer comparatively higher stress from the rest. Comparing the mean of the sample one $(\bar{x}=17.03)$ and sample two $(\bar{x}=17.40)$ also indicates that people, who are between 40 to 50 years and working in the bank $(\bar{x}=16.57)$ suffers less than the employees of the other industries $(\overline{\mathrm{x}}=18.38)$. Conversely, employees of the different industries $(\bar{x}=16.37)$, other than the bank are less stressful in between the age from 30 to 40. People working in the bank are least stressed above 50 years of age $(\bar{x}=16.28)$, and those who have above 10 years of experience $(\bar{x}=16.59)$. If people in different industries, other than the bank are considered, their stress tends to rise with their experiences, and begin to decline when they have above 10 years of experience. On the other hand, bank employees suffer high level of stress with the experience between 2 years to 5 years, and have the least stress if they manage to spend more than 10 years in the banking industry. Conversely, employees in the other industries have least stress in the first 2 years of their working lives. For detail, please consider Table 4. 
Table 1. Scale statistics

Scale Statistics

Sample One Sample Two

Standardized Regression Coefficients

Positive Worded Items (Self-efficacy)

Q1. In the last month, how often have you been upset because of something that happened unexpectedly?

$0.511 \quad 0.54$

Q2. In the last month, how often have you felt that you were unable to control the important things in your life?

$0.636 \quad 0.533$

Q3. In the last month, how often have you felt nervous and stressed?

Q6. In the last month, how often have you found that you could not cope with all the things that you had to do?

Q9. In the last month, how often have you been angered because of things that happened that were outside of your control?

Q10. In the last month, how often have you felt difficulties were piling up so high that you could not overcome them?

Negative Worded Items (Perceived helplessness)

Q4. In the last month, how often have you felt confident about your ability to handle your personal problems?

Q5. In the last month, how often have you felt that things were going your way?

Q7. In the last month, how often have you been able to control irritations in your life?

Q8. In the last month, how often have you felt that you were on top of things?

Model Fit Index

Minimum discrepancy/ degrees of freedom (CMIN/DF)

0.690

0.660

Comparative-fit index (CFI)

Goodness-of-fit-index (GFI)

Adjusted goodness of fit index (AGFI)

Root mean square error of approximation (RMSEA)

The Bentler-BonettNormed fit index (NFI)

Table 2. Perceived social stress in Sample 1

\begin{tabular}{|c|c|c|c|c|c|}
\hline \multirow{2}{*}{ Factors } & \multirow{2}{*}{ Category } & \multicolumn{3}{|c|}{ Perceived Social Stress } & \multirow{2}{*}{ Total } \\
\hline & & Low & Moderate & High & \\
\hline \multirow[t]{3}{*}{ Gender } & Male & 23.1 & 74.4 & 2.6 & 100.0 \\
\hline & Female & 30.1 & 62.8 & 7.1 & 100.0 \\
\hline & Total & 24.8 & 71.5 & 3.7 & 100.0 \\
\hline \multirow[t]{5}{*}{ Age (in years) } & $20-30$ & 23.4 & 72.5 & 4.1 & 100.0 \\
\hline & $30-40$ & 27.5 & 71.8 & 0.7 & 100.0 \\
\hline & $40-50$ & 23.1 & 71.2 & 5.8 & 100.0 \\
\hline & $50-60$ & 24.3 & 64.9 & 10.8 & 100.0 \\
\hline & Total & 24.8 & 71.5 & 3.7 & 100.0 \\
\hline \multirow[t]{14}{*}{ Industry } & Accounting \& Information & 14.3 & 81.0 & 4.8 & 100.0 \\
\hline & Agriculture & 40.0 & 50.0 & 10.0 & 100.0 \\
\hline & Architecture & 30.0 & 70.0 & 0.0 & 100.0 \\
\hline & Public Sector & 13.3 & 86.7 & 0.0 & 100.0 \\
\hline & Education & 29.0 & 71.0 & 0.0 & 100.0 \\
\hline & Financial \& Insurance & 22.6 & 77.4 & 0.0 & 100.0 \\
\hline & Health Sector & 21.9 & 69.9 & 8.2 & 100.0 \\
\hline & Information \& Publishing & 42.9 & 47.6 & 9.5 & 100.0 \\
\hline & Manufacturing of Basic Metals & 20.0 & 66.7 & 13.3 & 100.0 \\
\hline & Pharmaceuticals & 48.0 & 52.0 & 0.0 & 100.0 \\
\hline & Commercial Energy Sector & 20.0 & 80.0 & 0.0 & 100.0 \\
\hline & Real State \& Manufacturing & 22.5 & 75.0 & 2.5 & 100.0 \\
\hline & Non-governmental Social Service & 14.3 & 71.4 & 14.3 & 100.0 \\
\hline & Telecommunication & 15.6 & 78.1 & 6.2 & 100.0 \\
\hline
\end{tabular}




\begin{tabular}{|c|c|c|c|c|c|}
\hline \multirow{2}{*}{ Factors } & \multirow{2}{*}{ Category } & \multicolumn{3}{|c|}{ Perceived Social Stress } & \multirow{2}{*}{ Total } \\
\hline & & Low & Moderate & High & \\
\hline \multirow{8}{*}{$\begin{array}{l}\text { Experiences } \\
\text { years) }\end{array}$} & Textile & 28.3 & 71.7 & 0.0 & 100.0 \\
\hline & Tourism & 18.2 & 81.8 & 0.0 & 100.0 \\
\hline & Total & 24.8 & 71.5 & 3.7 & 100.0 \\
\hline & $0-2$ & 24.7 & 72.7 & 2.7 & 100.0 \\
\hline & $2-5$ & 23.9 & 71.6 & 4.5 & 100.0 \\
\hline & $5-10$ & 24.4 & 74.4 & 1.3 & 100.0 \\
\hline & Above 10 & 27.3 & 66.2 & 6.5 & 100.0 \\
\hline & Total & 24.8 & 71.5 & 3.7 & 100.0 \\
\hline
\end{tabular}

Table 3. Perceived social stress in Sample 2

\begin{tabular}{|c|c|c|c|c|c|}
\hline \multirow[b]{2}{*}{ Factors } & \multirow{2}{*}{ Category } & \multicolumn{3}{|c|}{ Perceived Social Stress } & \multirow{2}{*}{ Total } \\
\hline & & Low & Moderate & High & \\
\hline \multirow{3}{*}{ Gender } & Male & 24.6 & 70.9 & 4.5 & 100.0 \\
\hline & Female & 13.8 & 78.8 & 7.5 & 100.0 \\
\hline & Total & 22.5 & 72.4 & 5.1 & 100.0 \\
\hline \multirow[t]{5}{*}{ Age (in years) } & $20-30$ & 23.6 & 72.1 & 4.3 & 100.0 \\
\hline & $30-40$ & 22.1 & 71.1 & 6.9 & 100.0 \\
\hline & $40-50$ & 16.2 & 81.1 & 2.7 & 100.0 \\
\hline & $50-60$ & 28.1 & 71.9 & 0.0 & 100.0 \\
\hline & Total & 22.5 & 72.4 & 5.1 & 100.0 \\
\hline Experiences (in & $0-2$ & 26.1 & 67.0 & 6.8 & 100.0 \\
\hline \multirow[t]{4}{*}{ years) } & $2-5$ & 21.3 & 75.9 & 2.8 & 100.0 \\
\hline & $5-10$ & 20.4 & 73.7 & 5.8 & 100.0 \\
\hline & Above 10 & 23.8 & 71.2 & 5.0 & 100.0 \\
\hline & Total & 22.5 & 72.4 & 5.1 & 100.0 \\
\hline
\end{tabular}

Table 4. Descriptive statistics of social stress

\begin{tabular}{|c|c|c|c|c|c|c|c|}
\hline \multirow[t]{2}{*}{ Factor } & \multirow[t]{2}{*}{ Category } & \multicolumn{3}{|c|}{ Sample One } & \multicolumn{3}{|c|}{ Sample Two } \\
\hline & & $N$ & Mean & $\begin{array}{l}\text { Std. } \\
\text { Deviation }\end{array}$ & $N$ & Mean & $\begin{array}{l}\text { Std. } \\
\text { Deviation }\end{array}$ \\
\hline \multirow[t]{3}{*}{ Gender } & Male & 347 & 16.99 & 5.53 & 333 & 17.08 & 5.84 \\
\hline & Female & 113 & 17.16 & 6.03 & 80 & 18.73 & 5.20 \\
\hline & Total & 460 & 17.03 & 5.65 & 413 & 17.40 & 5.75 \\
\hline \multirow[t]{5}{*}{ Age } & $20-30$ & 222 & 17.09 & 5.64 & 140 & 17.48 & 5.54 \\
\hline & $30-40$ & 149 & 16.37 & 5.51 & 204 & 17.68 & 6.05 \\
\hline & $40-50$ & 52 & 18.38 & 5.46 & 37 & 16.57 & 4.88 \\
\hline & $50-60$ & 37 & 17.43 & 6.32 & 32 & 16.28 & 5.62 \\
\hline & Total & 460 & 17.03 & 5.65 & 413 & 17.40 & 5.75 \\
\hline \multirow[t]{5}{*}{ Experience } & 0 to 2 & 150 & 16.63 & 5.59 & 88 & 17.19 & 6.01 \\
\hline & 2 to 5 & 155 & 17.15 & 5.77 & 108 & 17.95 & 5.18 \\
\hline & 5 to 10 & 78 & 17.54 & 5.28 & 137 & 17.58 & 5.83 \\
\hline & Above 10 & 77 & 17.06 & 5.92 & 80 & 16.59 & 6.03 \\
\hline & Total & 460 & 17.03 & 5.65 & 413 & 17.40 & 5.75 \\
\hline
\end{tabular}

Table 5. Gender differences

\begin{tabular}{|c|c|c|c|c|c|c|c|}
\hline \multirow[t]{2}{*}{ Constructs } & \multirow[t]{2}{*}{$t$} & \multirow[t]{2}{*}{$d f$} & \multirow[t]{2}{*}{$\begin{array}{l}p \\
(2-\text { tailed })\end{array}$} & \multirow[t]{2}{*}{$\begin{array}{l}\text { Mean } \\
\text { Difference }\end{array}$} & \multirow[t]{2}{*}{$\begin{array}{l}\text { Std. Error } \\
\text { Difference }\end{array}$} & \multicolumn{2}{|c|}{$\begin{array}{l}95 \% \text { Confidence Interval of the } \\
\text { Difference }\end{array}$} \\
\hline & & & & & & Lower & Upper \\
\hline $\begin{array}{l}\text { Positive Worded Items } \\
\text { (Self-efficacy) }\end{array}$ & -1.419 & 871 & 0.156 & -0.5456 & 0.38457 & -1.30038 & 0.20919 \\
\hline $\begin{array}{l}\text { Negative Worded Items } \\
\text { (Perceived helplessness) }\end{array}$ & 0.899 & 871 & 0.369 & 0.2274 & 0.25304 & -0.26925 & 0.72405 \\
\hline Perceived social stress & -0.697 & 871 & 0.486 & -0.3182 & 0.45655 & -1.21427 & 0.57788 \\
\hline
\end{tabular}




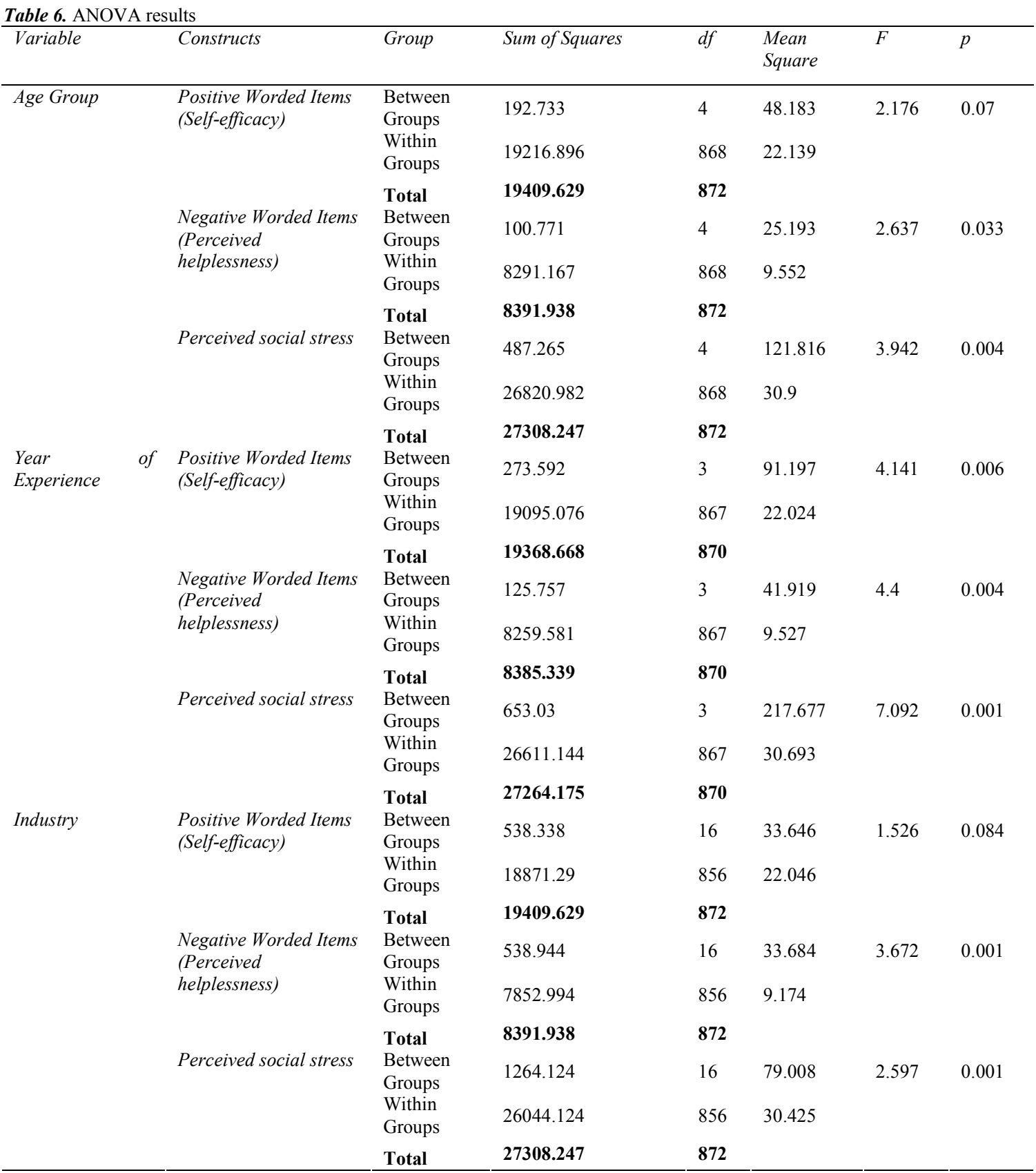

Comparison results

While the descriptive findings indicate the picture of who are more stressed than others, the statistical results need to be presented, for a properly comparison to be made. The $t$ test indicates that there is no significant statistical in accordance with gender and any of the constructs. The $t$ test result is shown in Table 5. The test of one way ANOVA indicates that the level of Self-efficacy does not vary significantly in accordance with age $(\mathrm{F}(4$, $868)=2.176, p=0.07)$ or the type of industry that the persons are being employed $(\mathrm{F}(16,856)=1.526, \mathrm{p}=$ $0.084)$. The only exception is the relationship between the level of Self-efficacy and the year of experience $(F(3,867)$
$=4.141, \mathrm{p}=0.006)$. However, significant statistical variations are visible in case of 'Perceived helplessness' with that of the age-category $(\mathrm{F}(4,868)=2.637, \mathrm{p}=$ $0.033)$, year of experience $(\mathrm{F}(3,867)=4.4, \mathrm{p}=0.004)$ and the types of industry $(\mathrm{F}(16,856)=3.672, \mathrm{p}=0.001)$ in which a person is involved. Similarly, significant statistical differences are found in case of 'Perceived social stress' with that of the Age-category $(\mathrm{F}(4,868)=3.942, \mathrm{p}=$ $0.004)$, year of experience $(\mathrm{F}(3,867)=7.092, \mathrm{p}=0.001)$ and the types a industry $(\mathrm{F}(16,856)=2.597, \mathrm{p}=0.001)$ person is involved. Please consider Table 6 for details. 


\section{Discussion}

Since most factors associated with economic activities and financial circumstances are the chief contributors, people living in developing nation that have very competitive job market, should be more stressful than the rest. Like all other developing nations, the job market of Bangladesh is very competitive, and the lack of systematic research made it complicated to define the exact condition. Near about 1.3 million youth enter the workforce each year mostly with a lack the fundamental knowledge or professional skills (World Bank Group, 2015). Employers often complain that the applicants have poor skills in English proficiency, computer-operating, communications, problem solving, decision making and entrepreneurship. Around 96 percent of the 57 million employees in the labor market have mere secondary education (World Bank Group, 2015). An incongruity between the nation's education system and job market forces contributes to the greater unemployment rate (Asadullah, 2014). Complains like political affiliation and family connections play a key role to achieve a good job in certain job sectors in the developing nations is not uncommon (Arasli \& Tumer, 2008). The size of the job market is not growing with expected pace, however the number of graduates entering to the market in large number. Hence, every year nearly half the total number of graduates enters the job market, but not getting jobs related to their field of study while the rest stay unemployed (Tribune-Report, 2015). Those who are employed, therefore, have a constant fear of losing their jobs and becoming the state of unemployment once again.

The study confers that Cohen's Perceived Stress Scale (PSS10) is a valid measure to address the issue of perceived stress in the context of Bangladesh. Though the study finds, in couple of instances, female are found to be more stressed up than that of male, the findings are not statistically conclusive. There is a difference between the level of stress among the young and the old employees, however, the nature of work or the type of industry one belongs to, play a pivotal role. Similar is the case for the year of experiences. It is conclusive to say that people in different industry perceived their level of stress differently. But, why some employees are more stressed than the others in various industries in Bangladesh?

Although, the answer lies beyond the capacity of the present study, nonetheless subjective interpretations of the situation can be formed based on previous literature. Some studies considered that conflict between the family and work (Reddy, Vranda, Ahmed, Nirmala, \& Siddaramu, 2010 ) or the poor performance expectations from females (Wheaton, 1983) generate greater stresses among the women than that of men, while others (Calvarese, 2015), like the present study found, indicate that there were hardly any differences as far as gender is concerned. Employees in their early stage of the career are more stressed up than the rest seems to be due to their high expectation from themselves, or they are in the industry that they did not prefer to be (Fox \& Spector, 1999). In the later part of the career they may have learn to deal with their stresses (Rees, 1997). Again middle-age crisis may also contribute to the high level of stress in 30 to 40 age-bracket (Steiner, 1973). People in the Non-governmental organizations are most stressed than the rest may be because they need to deal with the harsh reality of the world (Edelwich \& Brodsky, 1980). Manufacturing of Basic Metals and Agriculture sector generates more stress due to the working environment (Edelwich \& Brodsky, 1980). Seemingly, as the regional and international marketplace is drifting towards industry and services, the need for skilled labor force is expected; that may also contribute to job stress. In Bangladesh, Job market is agreeably depends on from where one has completed his or her graduation degree, and more often than not the skills in respective sector get the secondary considerations (Tribune-Report, 2015); nonetheless, the current research indicates that unlike other developing countries, the stress levels of the employees working in different industries are not apprehensive.

\section{Acknowledgement}

The authors would like to express their appreciation for the critical reviews that the anonymous reviewers made, which led to an improvement in the clarity and quality of the manuscripts.

\section{References}

Adler, N. E., Boyce, T., Chesney, M. A., Cohen, S., Folkman, S., Kahn, R. L., \& Syme, S. L. (1994). Socioeconomic status and health: The challenge of the gradient. American Psychologist, 49(1), 15-24. https://doi.org/10.1037/0003066X.49.1.15

Arasli, H., \& Tumer, M. (2008). Nepotism, Favoritism and Cronyism: a Study of Their Effects on Job Stress and Job Satisfaction in the Banking Industry of North Cyprus. Social Behavior and Personality: An International Journal, 36(9), 1237-1250. https://doi.org/10.2224/sbp.2008.36.9.1237

Asadullah, N. M. (2014, May 1). Is graduate unemployment rate really $47 \%$ ? | The Daily Star. The Daily Star. Retrieved from http://www.thedailystar.net/is-graduateunemployment-rate-really-47-22302

Avison, W. R., \& Turner, R. J. (1988). Stressful life events and depressive symptoms: disaggregating the effects of acute stressors and chronic strains. Journal of Health and Social Behavior, 29(3), 253-264. https://doi.org/10.2307/2137036

Bergdahl, J., \& Bergdahl, M. (2002). Perceived stress in adults: Prevalence and association of depression, anxiety and medication in a Swedish population. Stress and Health. https://doi.org/10.1002/smi.946

Burns, V. E., Drayson, M., Ring, C., \& Carroll, D. (2002). Perceived stress and psychological well-being are associated with antibody status after meningitis C conjugate vaccination. Psychosomatic Medicine, 64(6), 963-970. https://doi.org/10.1097/01.PSY.0000038936.67401.28

Calvarese, M. (2015). The Effect of Gender on Stress Factors: An Exploratory Study among University Students. Social Sciences, $4(4)$ 1177-1184. https://doi.org/10.3390/socsci4041177

Carpenter, L. L., Tyrka, A. R., McDougle, C. J., Malison, R. T., Owens, M. J., Nemeroff, C. B., \& Price, L. H. (2004). Cerebrospinal Fluid Corticotropin-Releasing Factor and Perceived Early-Life Stress in Depressed Patients and Healthy Control Subjects. Neuropsychopharmacology, 29(4), 777-784. https://doi.org/10.1038/sj.npp.1300375

Cohen, S., Kamarck, T. and Mermelstein, R. (1983). A Global Measure of Perceived Stress. Journal of Health and Social Behavior, 24(24), 386-396. https://doi.org/10.2307/2136404

Cohen, S., Doyle, W. J., \& Skoner, D. P. (1999). Psychological Stress, Cytokine Production, and Severity of Upper Respiratory Illness. Psychosomatic Medicine, 61(2), 175-180. https://doi.org/DOI: 10.1097/00006842199903000-00009 
Cohen, S., Kamarck, T., \& Mermelstein, R. (1983). A global measure of perceived stress. Journal of Health and Social Behavior, 24(4), 385-396. Retrieved from www.jstor.org/stable/2136404.

Cohen, S., Tyrrell, D. A., \& Smith, A. P. (1993). Negative life events, perceived stress, negative affect, and susceptibility to the common cold. Journal of Personality and Social Psychology, 64(1), 131-140. https://doi.org/10.1037/00223514.64.1.131

Cohen, S., \& Williamson, G. (1988). Perceived stress in a probability sample of the United States. The Social Psychology of Health. https://doi.org/10.1111/j.15591816.1983.tb02325.x

Cruess, D. G., Antoni, M. H., Kumar, M., Ironson, G., McCabe, P., Fernandez, J. B., ... Schneiderman, N. (1999). Cognitive-behavioral stress management buffers decreases in dehydroepiandrosterone sulfate (DHEA-S) and increases in the cortisol/DHEA-S ratio and reduces mood disturbance and perceived stress among HIVseropositive men. Psychoneuroendocrinology, 24(5), 537549. https://doi.org/10.1016/S0306-4530(99)00010-4

Culhane, J. F., Rauh, V., McCollum, K. F., Hogan, V. K., Agnew, K., \& Wadhwa, P. D. (2001). Maternal stress is associated with bacterial vaginosis in human pregnancy. Maternal and Child Health Journal, 5(2), 127-134. https://doi.org/10.1023/A:1011305300690

Dressler, W. W. (1988). Social consistency and psychological distress. Journal of Health and Social Behavior, 29(1), 79-91. https://doi.org/10.2307/2137182

Dyck, D. G., Short, R., \& Vitaliano, P. P. (1999). Predictors of burden and infectious illness in schizophrenia caregivers. Psychosomatic Medicine, 61(4), 411-419. https://doi.org/10.1097/00006842-199907000-00001

Ebrecht, M., Hextall, J., Kirtley, L.-G., Taylor, A., Dyson, M., \& Weinman, J. (2004). Perceived stress and cortisol levels predict speed of wound healing in healthy male adults. Psychoneuroendocrinology, 29(6), 798-809. https://doi.org/10.1016/S0306-4530(03)00144-6

Eckenrode, J. (1984). Impact of chronic and acute stressors on daily reports of mood. Journal of Personality and Social Psychology, 46(4), 907-918. https://doi.org/10.1037/00223514.46.4.907

Edelwich, J., \& Brodsky, A. (1980). Burn-Out - Stages of Disillusionment in the Helping Professions. New York: Human Sciences Press. Retrieved from https://www.ncjrs.gov/App/abstractdb/AbstractDBDetails. aspx?id $=70184$

Ementa, C. (2015). Secretaries' Perceived Strategies for Coping with Occupational Stress in Banks in Anambra State. African Research Review, 9(3), 88. https://doi.org/10.4314/afrrev.v9i3.8

Epel, E. S., Blackburn, E. H., Lin, J., Dhabhar, F. S., Adler, N. E., Morrow, J. D., \& Cawthon, R. M. (2004). Accelerated telomere shortening in response to life stress. Proceedings of the National Academy of Sciences, 101(49), 1731217315. https://doi.org/10.1073/pnas.0407162101

Farnworth, M., \& Leiber, M. J. (1989). Strain Theory Revisited: Economic Goals, Educational Means, and Delinquency. American Sociological Review, 54(2), 263. https://doi.org/10.2307/2095794

Fox, S., \& Spector, P. E. (1999). A model of work frustrationaggression. Journal of Organizational Behavior, 20(6), 915-931. $\quad$ https://doi.org/10.1002/(SICI)10991379(199911)20:6<915::AID-JOB918>3.3.CO;2-Y

Garg, A., Chren, M., L. P. Sands, Matsui, M. S., Marenus, K. D., Feingold, K. R., \& Elias, P. M. (2001). Psychological stress perturbs epidermal barrier homeostasis. Implications for the Pathogenesis of Stress-associated Skin Disorders. Arch Dermatol, 137, 53-59. https://doi.org/10.1001/archderm.137.1.53
George, E., \& K.A., Z. (2015). Job related stress and job satisfaction: a comparative study among bank employees. Journal of Management Development, 34(3), 316-329. https://doi.org/10.1108/JMD-07-2013-0097

Glaser, R., Kiecolt-Glaser, J. K., Marucha, P. T., MacCallum, R. C., Laskowski, B. F., \& Malarkey, W. B. (1999). Stress-related changes in proinflammatory cytokine production in wounds. Archives of General Psychiatry, 56(5), 450-456. https://doi.org/10.1001/archpsyc.56.5.450

Graham, J. M. (2006). Congeneric and (Essentially) TauEquivalent Estimates of Score Reliability What They Are and How to Use Them. Educational and Psychological Measurement, $\quad 66(6), \quad 930-944$. https://doi.org/10.1177/0013164406288165

Hair, J., Black, W., Babin, B., Anderson, R., \& Tatham, R. (1998). Multivariate data analysis (5(3)). New Jersey: Prentice hall $\quad$ Retrieved from https://pdfs.semanticscholar.org/6885/bb9a29e8a5804a71b f5b6e813f2f966269bc.pdf

Hewitt, P. L., Flett, G. L., \& Mosher, S. W. (1992). The Perceived Stress Scale: Factor structure and relation to depression symptoms in a psychiatric sample. Journal of Psychopathology and Behavioral Assessment, 14(3), 247257. https://doi.org/10.1007/BF00962631

Hölzel, B. K., Carmody, J., Evans, K. C., Hoge, E. A., Dusek, J. A., Morgan, L., ... Lazar, S. W. (2009). Stress reduction correlates with structural changes in the amygdala. Social Cognitive and Affective Neuroscience, 5(1), 11-17. https://doi.org/10.1093/scan/nsp034

Hyland, P., Boduszek, D., Dhingra, K., Shevlin, M., \& Egan, A. (2014). A bifactor approach to modelling the Rosenberg Self Esteem Scale. Personality and Individual Differences, 66, 188-192. https://doi.org/10.1016/j.paid.2014.03.034

Kishori, B., \& Vinothini, B. (2016). A Study on Work Stress Among Bank Employees in State Bank of India with Reference to Tiruchirappalli. IJIRST -International Journal for Innovative Research in Science \& Technology|, 2(12). Retrieved from http://ijirst.org/articles/IJIRSTV2I12133.pdf

Kramer, J. R., Ledolter, J., Manos, G. N., \& Bayless, M. L. (2000). Stress and metabolic control in diabetes mellitus: Methodological issues and an illustrative analysis. Annals of Behavioral Medicine, 22(1), 17-28. https://doi.org/10.1007/BF02895164

La Gory, M., Ritchey, F. J., \& Mullis, J. (1990). Depression among the homeless. Journal of Health and Social Behavior, 31(1), 87-102. https://doi.org/10.2307/2137047

Lane, J. D., Seskevich, J. E., \& Pieper, C. F. (2007). Brief meditation training can improve perceived stress and negative mood. Alternative Therapies in Health and Medicine, 13(1), 38-44. https://doi.org/10.1097/ANC.0000000000000235

Lazarus, R. S., \& Folkman, S. (1987). Transactional theory and research on emotions and coping. European Journal of Personality, 1(3), 141-169. https://doi.org/10.1002/per.2410010304

Leon, K. A., Hyre, A. D., Ompad, D., DeSalvo, K. B., \& Muntner, P. (2007). Perceived stress among a workforce 6 months following hurricane Katrina. Social Psychiatry and Psychiatric Epidemiology, 42(12), 1005-1011. https://doi.org/10.1007/s00127-007-0260-6

Lopes, C., \& Kachalia, D. (2013). Impact Of Job Stress On Job Satisfaction Of Employees Working In Banking Sector. International Journal of Science Tachnology and Management, 5(1988), 103-115.

Maes, M., Van Bockstaele, D. R., Van Gastel, A., Song, C., Schotte, C., Neels, H., ... Janca, A. (1999). The effects of psychological stress on leukocyte subset distribution in humans: Evidence of immune activation. 
Neuropsychobiology, https://doi.org/10.1159/000026552

Malarkey, W. B., Pearl, D. K., Demers, L. M., Kiecolt-Glaser, J. K., \& Glaser, R. (1995). Influence of academic stress and season on 24-hour mean concentrations of ACTH, cortisol, and $\beta$-endorphin. Psychoneuroendocrinology, 20(5), 499-508. https://doi.org/10.1016/03064530(94)00077-N

Marcus, M. T., Fine, P. M., Moeller, F. G., Khan, M. M., Pitts, K., Swank, P. R., \& Liehr, P. (2003). Change in stress levels following mindfulness-based stress reduction in a therapeutic community. Addictive Disorders \& Their Treatment, 2(3), 63-68. Retrieved from http://journals.lww.com/addictiondisorders/Abstract/2003/ 02030/Change_in_Stress_Levels_Following.1.aspx

McAlonan, G. M., Lee, A. M., Cheung, V., Cheung, C., Tsang, K. W. T., Sham, P. C., ... Wong, J. G. W. S. (2007). Immediate and sustained psychological impact of an emerging infectious disease outbreak on health care workers. Canadian Journal of Psychiatry. Revue Canadienne de Psychiatrie, 52(4), 241-247. https://doi.org/10.1177/070674370705200406

Misigo, B. L. (2015). Gender difference in the perceived level of stress and coping strategies among university students in Kenya: A case of public universities. International Academic Journal of Social Sciences and Education, 1(4), 44-52. Retrieved from http://iajournals.org/articles/iajsse v1 i4 44 52.pdf

Nunnally, J. C., \& Bernstein, I. H. (1994). PSYCHOMETRIC THEORY THIRD EDITION. In PSYCHOMETRIC THEORY (Vol. 1). https://doi.org/34567890 DOCmoC 998765 ISBN

Osmanovic-Thunström, A., Mossello, E., Åkerstedt, T., Fratiglioni, L., \& Wang, H. X. (2015). Do levels of perceived stress increase with increasing age after age 65 ? A population-based study. Age and Ageing, 44(5), 828834. https://doi.org/10.1093/ageing/afv078

Pearlin, L. I. (1989). The sociological study of stress. Journal of Health and Social Behavior, 30(3), 241-256. https://doi.org/10.2307/2136956

Pearlin, L. I., \& Lieberman, M. A. (1979). Social sources of emotional distress. Research in Community and Mental Health, 1, 217-248.

Pruessner, J. C., Hellhammer, D. H., \& Kirschbaum, C. (1999). Burnout, Perceived Stress, and Cortisol Responses to Awakening. Psychosomatic Medicine, 61(2), 197-204. https://doi.org/10.1097/00006842-199903000-00012

Reddy, N. K., Vranda, M. N., Ahmed, A., Nirmala, B. P., \& Siddaramu, B. (2010). Work-Life Balance among Married Women Employees. Indian Journal of Psychological Medicine, 32(2), 112-8. https://doi.org/10.4103/02537176.78508

Rees, W. D. (1997). Managerial stress - dealing with the causes, not the symptoms. Industrial and Commercial Training, 29(2), 35-40. https://doi.org/10.1108/00197859710164994

Roberti, J. W., Harrington, L. N., \& Storch, E. A. (2006). Further Psychometric Support for the 10-Item Version of the Perceived Stress Scale. Journal of College Counseling, $9(2), \quad 135-147 . \quad$ https://doi.org/10.1002/j.21611882.2006.tb00100.x
Russo, J., Miller, D., \& Vitaliano, P. P. (1985). The relationship of gender to perceived stress and distress in medical school. Journal of Psychosomatic Obstetrics \& Gynecology. https://doi.org/10.3109/01674828509085267

Samartha, V., Begum, M., \& Lokesh. (2014). A comparative analysis of occupational stress among the employees in public and private sector banks in dakshina kannad district. International Journal of Conceptions on Management and Social Sciences, 2(2), 2357-2787. Retrieved from http://www.worldairco.org/IJCMSS/May2014paper M5.pdf

Sapolsky, R. M. (2004). Why zebras don't get ulcers: A guide to stress, stress related diseases, and coping. Natural History. https://doi.org/10.1002/cir.3880060119

Stark, J. L., Avitsur, R., Padgett, D. A., Campbell, K. A., Beck, F. M., \& Sheridan, J. F. (2001). Social stress induces glucocorticoid resistance in macrophages. $\mathrm{Am} \mathrm{J}$ Physiol Regulatory Integrative Comp Physiol, 280(6), R1799-1805. https://doi.org/10.1146/annurev.ps.44.020193.000413

Steiner, B. W. (1973). The crisis of middle age. Canadian Medical Association Journal, 109(10), 1017-20+27.

Stone, A. A., Mezzacappa, E. S., Donatone, B. A., \& Gonder, M. (1999). Psychosocial stress and social support are associated with prostate-specific antigen levels in men: Results from a community screening program. Health Psychology, 18(5), 482-486.

Taylor, J. M. (2015). Psychometric analysis of the ten-item perceived stress scale. Psychological Assessment, 27(1), 90-101. https://doi.org/10.1037/a0038100

Tribune-Report. (2015, April 21). Graduates mismatch with job market demand. Dhaka Tribune. Dhaka. Retrieved from

http://archive.dhakatribune.com/business/2015/apr/21/grad uates-mismatch-job-market-demand

Turner, R. J., \& Noh, S. (1988). Physical Disability and Depression: A Longitudinal Analysis. Journal of Health and Social Behavior, 29(1), 23-37. https://doi.org/10.2307/2137178

United Nation. (2015). United Nations Statics Division Classifications Registry. Retrieved from http://unstats.un.org/unsd/cr/ctryreg/ctrydetail.asp?id=138 0

Van Eck, M., Berkhof, H., Nicolson, N., \& Sulon, J. (2005). The effects of perceived stress, traits, mood states, and stressful daily events on salivary cortisol. Psychosomatic Medicine, 58(5), 447-458. https://doi.org/10.1097/00006842-199609000-00007

Wheaton, B. (1983). Personal and Psychiatric Stress, Coping Resources, Symptoms: An Investigation of Interactive Models. Journal of Health and Social Behavior, 24(3), 208-229.

WORLD BANK GROUP. (2015). In Bangladesh, A STEP forward toward Success. Washington, DC. Retrieved from http://www.worldbank.org/en/news/feature/2015/10/20/inbangladesh-a-step-forward-to-success 